„Bohemistyka” 2020, nr 1, ISSN 1642-9893

Miroslav KotÁSEK

Masarykova univerzita

\section{Hranice, možnosti a úlohy komentáře (Jiří Kratochvil, Ludvík Vaculík)}

Keywords: Jiří Kratochvil, metacommentary, the postmodern, posthermeneutics, Ludvík Vaculík

Klíčová slova: Jiří Kratochvil, metakomentář, postmoderna, posthermeneutika, Ludvík Vaculík

\section{Abstract}

The article focuses generally on the functioning of commentary or metacommentary within postmodern narrative texts. Two Czech authors from the second half of the 20 th century have been chosen to illustrate the theory outlined in the introductory part of the article: Ludvík Vaculík and Jiři Kratochvil. From the point of view of interpretation the structure that is being opened by commentary inside some narratives is called posthermeneutic. The article argues that posthermeneutic situation can be found in the perverse situation of samizdat publishing in Czechoslovakia in the 1970s (as depicted by Vaculík's Český snár) and in the role played by women in Kratochvil's short story Př́běh krále Kandaula. The article concludes that the postmodern might stand the reader in front of an ethical choice as far as the function of literature and art is concerned.

Na obecné úrovni se článek zabývá fungováním komentáře či metakomentáře v postmoderních prozaických textech. K doložení a rozpracování teoretických východisek využívá článek texty Jiřího Kratochvila a Ludvíka Vaculíka. Z pohledu hermeneutiky je struktura, která se odhaluje uvnitř literárních textů právě prostřednictvím komentáře, nazvána posthermeneutickou. Článek ukazuje, že tato posthermeneutická struktura je pevně spojena s perverzní situací ineditního publikování v Československu 70. let jak ji zachycuje Vaculíkův Český snář, stejně jako se situací ženského subjektu zobrazené v Kratochvilově povídce Př́běh krále Kandaula. Článek dochází $\mathrm{k}$ závěru, že postmoderna staví čtenáře či recipienta před etickou volbu co se role literatury a obecně umění týče.

\section{Úvod}

S odvoláním na fascinaci postmoderny slovem a na roli, již podle ní hraje jazyk v každodenním životě, literatuře a obecně v západní kultuře, bývá postmoderna označována za „logocentrickou”. Jane Flaxová tvrdí, že postmoderní filozofie (reprezentovaná dle ní Richardem Rortym, Michelem Foucaultem a Jean-Françoisem Lyotardem) vede k nutnému závěru, že ,pokud je všechna zkušenost textová nebo interpretační, není možné způsoby myšlení oddělit od způsobů bytí” (Flax 1991, s. 193). Na př́kladu Kratochvilovy povídky Př́běh krále Kandaula (ze sbírky povídek Orfeus z Kénigu, 1994) a Vaculíkova Českého snáre (1981) se pokusím poukázat na to, že právě postmoderní próza může potenciálně otevírat zcela konkrétní nejazykovou problematiku, v níž literatura, a tedy i jazyk obecně, narážejí na hranice svých možností, nebo spíše dokládají, v čem je fundování ontologie skrze symbolismus jazyka využívaný lidským rozumem, kognicí, pamětí a tvořivostí, který tyto schopnosti zároveň strukturuje a vymezuje, nedostatečné. „Preontologická dimenze”, která se tu hlásí o slovo, je jakousi temnou či negativní stránkou zdánlivě omnipotentního slova či pojmu: podle Hegela, jak jej vykládá Žižek,

[...] nedostatečnost našeho poznání (naše neschopnost uchopit celek bytí, způsob, jímž se naše poznání neodvratně zaplétá do rozporů a nekonzistencí) je zároveň nedostatečnost samotného našeho předmětu poznání; mezery a prázdná místa v našem poznání reality jsou zároveň mezerami a prázdnými místy v samotné ,skutečné ontologické budově (Žižek 2007, s. 65)

Netvrdím, že právě literatura nám zpř́stupňuje tuto preontologickou dimenzi, že nám dovoluje zkoumat nedostatky v ontologické struktuře světa; bude mě zajímat, jakým způsobem uvnitř jazykového režimu přesahují zmíněné texty sféru jazykovou, oblast interpretace. Tuto možnost ostatně na rozdíl od simplifikujího výkladu Flaxové postmoderní teorie alespoň v některých svých podobách předpokládá, když pojímá postmodernu jako „to, co zkoumá nové prezentace nikoli proto, aby se z nich čerpalo potěšení, ale aby se lépe vycitovalo, že existuje neprezentovatelné" (Lyotard 1993, s. 28). 
Jak chápat $\mathrm{v}$ této souvislosti roli komentáře? Komentář nemusí být jen záznamem již provedené interpretační práce; Tomáš Jirsa ve své knize Tváři v tvář beztvarosti vychází z poznatku, který později přesvědčivě dokumentuje, že totiž umělecká díla „,dokážou prostřednictvím svého jazyka a imaginace rovněž podnítit vlastní pojmy, koncepty, a dokonce i teorie" (Jirsa 2016, s. 32), přičemž se tak dle něj děje skrze „figury”. V poněkud jiném významu než pro Jirsu představuje pro mě právě takovou „figuru” komentář a jeho rozdílné podoby. Platí tu v konkrétním smyslu, že ,postmoderní spisovatel je v situaci filosofa: text, který píše [...] se neřídí v zásadě pravidly už stanovenými [...] pravidla a [...] kategorie jsou tím, co dílo nebo text hledá" (Lyotard 1993, s. 28).

Jistý paradox je možné vidět v tom, že v principu by měl komentár̆ jakékoli pochybnosti o schopnostech jazyka při zachycení reality či skutečnosti smazávat nebo zastírat, nebot' jakoukoli nespojitost je schopen „okomentovat” tím, že se jazyk posune o úroveň výš, na rovinu metajazykovou, kam má „komentář” prizmatem jazykových funkcí náležet. Pokud má komentář mít onu vypovídací hodnotu, kterou mu přisuzuji, má-li být samostatnou „figurou”, potom je nutné se rozejít s představou, že využívá „metajazyka”. Jakkoli formálně může v postmoderně komentář nést znaky meta-narativní, meta-jazykové, z pohledu funkce či ,smyslu” komentáře už není možné prostě ,komentovat", tedy se neochvějně (naivně) nalézat na metajazykové úrovni: komentář sám obsahuje implicitní komentář své vlastní limitované použitelnosti a zpochybňuje topologii vnitřku a vnějšku stejně jako dyádu subjektu a objektu (naprríklad prostřednictvím metafory záhybu, kde vnitřní je záhybem vnějšího). Komentář je v tomto smyslu vlastně postmoderním, symptomem” - vezmeme-li vážně tezi o logocentristické postmoderně, potom by ji nejdokonaleji dokládal právě vnitřnětextový komentár, který se obrací jen $\mathrm{k}$ jazyku. A to proto, protože komentář je zbaven postmoderního strašidla reference, reprezentace či reality tím, že se vztahuje jen k dalším slovům, větám, textům, žánrům. A tento z principu dodatečný, suplementární, marginální text se tak může stát centrem či fundamentem logocentristického pojetí postmoderny: fundamentem jistě ne-fundamentálním, nebot' komentář k textu (prríběhu) přistupuje zvnějšku právě jako jeho dodatek a zaujímá tak vůči němu pozici okrajovou. Pokud však je funkce komentáře vskutku takto paradoxně „,centrální”, potom nemůže být meta-jazyková. A zároveň je tato topologie zárukou, že se postmoderní text neocitne v bludném kruhu sebeevidence.

Přiznání možnosti, že ,textová a interpretační zkušenost” není zkušeností celou či jedinou, vede k problematizaci výše naznačeného vztahu mezi myšlením a bytím (vztahu z pohledu postmoderny v principu epistemologického). Další možnost, zapříčiňující, že tato oblast je relevantní i pro postmodernu, může spočívat v tom, že se v postmoderně oproti moderně mj. také proměnil způsob interpretace, přičemž podle Žižka je

[...] modernistickým postupem „výklad symptomư”: při konfrontaci s totalitou usiluje moderna o její subverzi tím, že odhaluje stopy její skryté pravdy v detailech, které „vyčnívají" a usvědčují ze lži ,oficiální" " pravdu, stejně jako na okrajích, které odkazují na to, co bylo „potlačeno”, aby se mohla ustavit oficiální totalita - základním modernistickým axiomem je, že detaily vždy obsahují nějaký přebytek, který podkopává obecný rámec „oficiální” Pravdy (Žižek 1992, s. 120),

zatímco postmodernismus - podle něj - je

[...] posedlý Věcí, cizím tělesem uvnitř sociální struktury, a to ve všech jejích podobách od ženy jakožto nerozluštitelného elementu, jenž podkopává působení ,principu reality $[$ [...] po paranoidní vizi sociální totality jako ultimativní fascinující Věci, upírského př́zraku, který poznamenává dokonce i ten nejidyličtější všední den znaky latentního rozkladu (Žižek 1992, s. 122).

Povídka Jiř́ho Kratochvila by odpovídala oné posedlosti (v daném konkrétním případě příznačně nemluvnou) ženou, Vaculíkův román by byl př́ikladem (jakkoli opodstatněné) paranoie konce sedmdesátých let tváří v tvář reálnému normalizačnímu socialismu. V obou textech pak hraje důležitou roli otázka těla a tělesnosti a jejich propojení s jazykem spolu s (ne)možností vykládat (reflektovat) fyzicko-materiální dimenzi lidské existence. 
Provizorně budu oblast, která se zde negativně rýsuje, označovat jako ,posthermeneutickou”. Fredric Jameson ve svém článku pojmenovaném „Metacommentary" hovoří o ,posthermeneutické situaci” především $\mathrm{v}$ souvislosti $\mathrm{s}$ takovými díly, která se prostřednictvím vědomého tvůrčího aktu vzpírají interpretaci, přičemž nedostatečnost interpretace se objevuje př́mo v textu jako touha po neinterpretovatelnosti, neprůhlednosti smyslu. Jameson v této souvislosti poukazuje na modernistické experimenty z konce 19. století (např. Stephana Mallarméa) a počátku 20. století. Jakkoli nepřejímám Jamesonův termín „posthermeneutická situace” v doslovném významu, který mu dává, přesto je pro mě jeho pohled relevantní (srov. také Mersch 2010).

„Neinterpretovatelnost” nabývá ve Vaculíkově Českém snáři a v Kratochvilově povídce několika podob, přičemž je přímo v textech komentována, což by bylo možné bez váhání označit za typicky ,,postmoderní" narativní postup. Pro tento komentář platí, že je nesen na jedné straně fascinací plynoucí z propojení mezi jazykem a obývaným či vyprávěným světem, na druhou stranu však nejsou tento vztah ani možnosti jeho popisu vnímány naivně. Rozmanité podoby komentování spolu se samotným nutkáním komentovat dokumentují nedostatečnost komentáře. Ta si vynucuje další komentář atd., potenciálně ad infinitum. Jak jsem však již uvedl, neděje se tak v podobě soustředných meta-jazykových kruhů, ale spíše v podobě série. Komentáře dokumentují nedostatečnost interpretace, její hranice a v ideálním případě ji mají kompenzovat. Bud' proto, že neumím číst, a co čtu, čtu špatně. Nebo proto, že samotný text vždy byl „chybný”, defektní prostě proto, že jeho autor měl k dispozici pouhá slova. Jameson ve stručnosti popisuje celou situaci takto: „Všechno myšlení o interpretaci se propadá do podivnosti, nepřirozenosti hermeneutické situace. Jinými slovy: každá jednotlivá interpretace musí obsahovat interpretaci své vlastní existence, musí osvědčit své vlastní pověření, odůvodnit se - každý komentář musí být zároveň metakomentářem. Skutečná interpretace tak vede pozornost $\mathrm{k}$ historii a $\mathrm{k}$ historické situaci komentátora stejně jako díla" (Jameson 1971, s. 10). Interpretace tak není jednoduchá, intuitivní, bezproblémová, snad je v konkrétním smyslu ne-možná.

Ještě poněkud jiná východiska volí Julia Kristeva při svém uvažování o ,postanalytickém osudu interpretace”:

Dnešní interpret se vyhýbá tomu, aby se subjekty mezi sebou navzájem potkávaly nebo přicházely do kontaktu s interpretovanými předměty. V tomto potkávání, v této souběžné př́itomnosti, vyvstává totiž před promlouvajícími subjekty podivný objekt, jakási záruka, kterou sami sobě přinášejí - totiž interpretace -, která je ujišt'uje, že jsou skutečně tam, kde se nacházejí, že jsou si blízko, na dosah. Pokud se nový interpret oprostí od definitivní př́tomnosti významu, již neinterpretuje: mluví a činí asociace, protože už neexistuje objekt, který by bylo možné interpretovat; namísto toho se tu rozehrávají sémantická, logická, fantasmatická a nerozhodnutelná spojení. Ve výsledku se zjevuje fikce, diskurz bez středu, subjektivní polytopie, která ruší metajazykový status diskurzu vládnoucí postanalytickému osudu interpretace (Kristeva 1986, s. 306)

Kristevová tedy postuluje nemožnost meta-pozice, problematizuje vztah subjektu a objektu. Jak jsem již konstatoval, metapozice se stává problematickou či neudržitelnou i v rámci postmoderních textů, v nichž se zdá, že je to právě ona, která má být zdrojem komentáře, což následně umožňuje naratologii hovořit o tzv. „vnořených” (embedded) diskurzech nebo jednotlivých „úrovních” vyprávění (k metadiegezi a metalepsi viz Genette 1983, s. 231-237; Genette 1988, s. 84-96) naratologie se tu opírá o víru v objektivizující metadiskurz (narativ nižší úrovně se stává objektem narativu úrovně vyšší).

\section{Př́ípad Vaculík}

Zdálo by se, že v Českém snáři, kde jsou literatura a obecně jazyk všudypř́ítomné, a vlastně nevyhnutelné, zasahují všechny oblasti života, je marné hledat nějaký exces, nedořečenost, mimojazykový přesah. A přece: ono nutkání komentovat jazykové akty, popis řečových strategií (např. vzhledem k hrozbě odposlechů: „Kolik exemplářù toho děláš?" zeptal jsem se tužkou. Napsal odpověd' a zachechtal se tomu směšnému nákladu; Vaculík 1990, s. 8), reflektovat postup vzniku textu, jeho redigování apod. dokládají v konkrétním smyslu ne- 
smyslnost, nesamozřejmost, absurditu či vyšinutost dobové situace. Psaní je tu pevně svázáno s dobou vzniku textu, s politickou a kulturní situací doby, která ve velké míře deformuje a predeterminuje, co bude napsáno či řečeno a jak (důsledky pro interpretaci pojmenovává výše uvedený Jamesonův citát).

Jako jeden z korektivů uvedené deformace by mohl posloužit pojem ,žánru" (nebot' ten by měl být díky své abstraktnosti schopen dobový kontext přesáhnout). Žánrem chápu soubor diskurzivních (literárních, narativních, kompozičních) postupů užitých v textu, které směrem k recipientovi předznamenávají a signalizují správné a očekávané zpo̊soby čtení. Žánr zprostředkovává kognitivní a interpretační vodítka, která by měla zajistit spolehlivost přenosu jazykových a jiných významů. Ve Vaculíkově Českém snáři stojí v cestě takovému „přenosu” již to, že samotné žánrové vymezení je deformováno: stává se předmětem komentáře a zpochybnění, at' už explicitního nebo implicitního. Mísení románu, deníku, dopisů, esejů apod. zmíněnou žánrovou garanci přinejmenším suspenduje - ve výsledku tak může Sylvie Richterová v souvislosti s žánrovou charakterizací Českého snáře konstatovat, že ,je to román psaný jako deník a deník psaný jako román" (Richterová 1991, s. 107), Milan Suchomel pak, že se tu „deník mění v román” (Suchomel 1997, s. 421).

Nedomnívám se, že tu Vaculík prostě využívá „typické” postmoderní hybridizace žánrů či znejist'ování jejich hranic. Spíše poodhaluje důvod, co k takovému mísení může vést: tedy nemožnost opírat se v literatuře vznikající v ,nesmyslné” situaci o jednoznačnou (v tomto prrípadě mj. žánrovou) garanci smyslu. A to z důvodu, který popisuje Sylvie Richterová takto:

Člověk [...] začal pohlížet na sebe především jako na znak. Nevyřešená otázka identity člověka se nepozorovaně proměnila $\mathrm{v}$ otázku identity znaku. Jestliže se člověk převtělí ve znak, projde, nevěda třeba ani jak, hranici, která ruší vztah znaku ke skutečnosti. Konec možného dorozumění prožívá jako katastrofu. Ale ne proto, že by touto proměnou ztrácel smysl. Katastrofa tkví v tom, že jeho smysl je nyní daný znakovým systémem, $v$ němž se ocitá, $v$ němž může být podle jím nekontrolovaného klíče libovolně označen za cokoliv a mimo který neexistuje (Richterová 1991, s. 69).
„Román” a „deník” vlastně dokumentují dva základní režimy „vztahu znaku ke skutečnosti”, které jsme většinou připraveni chápat jako protichůdné: ,fikci” a ,non-fikci”.

Za nejdůležitější, čtenáři intuitivně přijímanou, vlastnost deníku, jíž se odlišuje od „fikce” by měl být jeho privátní charakter; deník se chápe jako pokus o popis či rekonstrukci lidské intimity, neopakovatelnosti (a zároveň všednosti) lidské situace. Při hlubším pohledu vyplyne, že tento pokus je marný: intimita a všednost jsou v deníku zapsány, čitelné, a tedy (potenciálně) veřejné. Z tohoto pohledu není nic zvláštního na tom, že se deník stává literaturou, mění se v román, ba právě naopak: jako by se teprve tímto přechodem naplnilo to, k čemu deník již vždy směřuje (praxe dobových domovních prohlídek a odposlechů dokládá tuto možnost z jiné strany: nic není soukromé). Proto také může Vaculík začít psát svůj deník jako literární text a od začátku uvažovat o jeho zveřejnění.

Proklamovaná intimita jako by byla svým zapsáním v deníku mnohem spíše gestem jejího prolomení, hledáním jiného člověka, se kterým je možné se o ni podělit, a toto hledání je v př́ípadě deníku samozrrejmě především hledáním čtenáře. Richterová poukazuje v souvislosti s Českým snářm na část zabývající se postavou Heleny a jejím odjezdem do emigrace, který zůstává v době, kdy se událost stala, (deníkově) nezapsaná, a teprve časem se k ní zapisovatel vrací. Skutečně intimním je podle Richterové to, co zůstává nenapsáno (i když postupně je ona scéna přece jen popsána). Přesto i toto mlčení musí být nějakým způsobem zpodobněno, v textu musí vystupovat alespoň obrysy oné černé díry, která je pro nás mlčením (nezapsáním), chyběním. Vaculík tento aspekt dokonce vizualizuje tím, že z fotografie panoramatu Pražského hradu Helenu (v oficiálním, polistopadovém vydání) vystřihuje, takže z ní zůstává pouhý „magrittovský” obrys (Vaculík 1990, s. 167). Vynechává tedy teprve cosi, co již bylo jistým způsobem zachyceno, dokumentováno, zobrazeno.

Pokud bychom chtěli spolu s Richterovou hodnověrně hovořit o tom, co zůstalo nezapsáno, bylo by nutné vědět, čteme-li „deník”, nebo „román”. Fikční prŕíběh nikdy neexistuje před svým napsáním, 
ten se rodí teprve se svým zápisem, a proto jej nikde nepřebývá a nikde nechybí. Př́iběh toho, kdo o sobě píše deník, je naproti tomu vždy již vybaven distancí, je to vždy něco, co se již stalo, je to vždy již zápis paměti a nikoli toho, co se „opravdu” stalo. „Opravdu” se zde děje jen vzpomínání (ve formě psaní). A samozřejmě následná revize textu, mazání, zamlčování, anonymizace dalších postav. V deníku se děje popisování prožitého, při psaní románu se tvoří př́iběh. V jistém smyslu je tedy fabulace př́běhu dokonce ,skutečnějšś” než deníkový zápis a deník dokonce literárnější než literatura. Problémem je, že Vaculík mnohdy nepozorovaně, jindy hmatatelněji či dokonce explicitně „fabuluje”, zatímco na jiném místě je psaní ztotožňováno se životem, s osudem. A redigování, ke kterému se Vaculík přiznává, i to, ke kterému se eventuelně nepřiznává, není tedy jen redigováním příběhu, ale především redigovaním paměti. Je to především toto (paranoidní) vědomí, které otevírá posthermeneutický přístup: vím, že jsem vepsán do nějakého př́běhu - formuluji tedy pro sebe důsledky, které pro mě toto vědomí představuje.

„Deník” zde tedy nezastupuje sféru intimní a neveřejnou, stejně jako „román” neaspiruje stát se veřejným, nadčasovým „dílem”. Tyto možnosti nestojí proti sobě:

Potom jsem návazně přečetl své deníky dělnické a studentské, a co vidím: že já mám napsáno vše. A že jsem si to napsal naprosto včas. Pozdější prací jsem své názory a postoje už jenom varioval a ilustroval. Nebyl jsem nikdy moudřejší ani schopnější, než jsem byl do dvaceti let. Všecko se splnilo, došlo na má nejhorší tušení, zatímco mé hojivé naděje neměly v ničem pravdu. Nejenom úspěchy, ale i všecky své nezdary, poklesky i pády jsem si jakoby předepsal do partitury a potom je přehrával (Vaculík 1990, s. 20-21).

Zde se dokonce psaní v konkrétním smyslu zmocňuje svého pisatele, přičemž jeho ,skutečný život” už ani nepotřebuje: vše je napsáno, vše je předpovězeno, nic nás nemůže překvapit, lze pouze vyrábět variace již hotového. Ale je to také hra na schovávanou: já, který předstírám, že tady píšu, zde nejsem, v tomto textu mě nenaleznete, jsem již napsán jinde a jinak.
Kdy a za jakých okolností přestává být „Vaculík”,„znakem”? Již jsem zmínil, že jazyk či literatura jsou v Českém snáři vlastně všudyprítomné. Stejně tak je možné souhlasit se Sylvií Richterovou, že v Českém snáři nalézáme ,potencionální možnost, aby se všechno stalo v Českém snáři zprávou, řečí, znamením” (Richterová 1991, s. 120). A přece je právě kontakt s literaturou alespoň v některých jeho podobách cestou mimo znaky, mimo slova: jako vydavatel samizdatu je Vaculík konfrontován s těmi aspekty literatury, které má běžný čtenář tendenci opomíjet. Literaturu lze totiž vnímat více smysly než jen sledovat zrakem písmena na stránce: kniha má svou váhu, kniha voní, je možné se jí dotýkat, hladit ji. Aby vznikla ineditní tiskovina, bylo třeba ji úmorným způsobem přepsat, vyzvednout přepsané stránky, dopravit k vazači, odnést svázané výtisky, distibuovat, vybrat peníze. Literatura je tu př́mo napojena na tělesnou práci zúčastněných osob; kniha je doslova a do písmene těžká, pronese se. Asi nelze říci, že se tu ocitá literatura mimo význam a smysl, ale spíše to, že ten je alespoň v jedné své podobě primárně tělesný: neznakový. Samozřejmě je následně možné tuto „existenciální” dimenzi literatury uchopit či popsat v př́běhu (který bude potřeba přepsat, svázat atd.). Snad je tedy význam vždy už, vždy především „tělesný” - narážíme tu na vztah smyslu a tělesného, kterému kognitivní věda říká embodiment. Literatura je materiální, a obcování s ní přináší existenciální rizika (výslechy, vězení). Také všední život se točí především kolem literatury, knih, prríběhů - to jsou všechny ty postavy, s nimiž se vypravěč potkává a které v románu hrají tu více, tu méně důležitou roli: Karel Kosík, Jiří Gruša, Ivan Klíma, Eva Kantůrkova, Václav Černý, Jiří Kolář, Eda Kriseová ad.

Literatura je $\mathrm{v}$ české společnosti tradičně spojována s politikou a spisovatelé často suplovali neexistující veřejný rozměr politiky. Kratochvil poznamenává:

[...] od té chvíle [od 2. pol. 60. let 20. století - M.K.] se čeští spisovatelé stávají (a většina $z$ nich samozřejmě proti své vůli) členy jakési nikdy neustavené a nikdy nepojmenované politické opoziční strany a taky je s nimi od počátku sedmdesátých 
let nakládáno jako s politickými spiklenci, kteří prohráli svůj boj s mocí a ponesou si ted' zasloužené následky (Kratochvil 2005, s. 286).

Dochází k perverznímu spojení: literátské ghetto (,jakákoli horečná literární aktivita je už dnes čím dál líp obezděným ghettem"; Kratochvil 2005, s. 294) je ve smysluplnosti svého snažení ujištováno především státní mocí (pro niž je literatura také „vážná” a „závažná”), ta má však toto snažení zároveň za úkol potírat. A Vaculík vlastně napsáním Českého snáře dopředu odmítá námitky živých předobrazů postav z Českého snáre, které se na stránkách textu objevují pod vlastními jmény, že tím dal vlastně do rukou StB informace, které by jinak neměla, nebo by je musela pracně získávat. Není to spíš tak, že Vaculík nahližźi naznačenou perverznost situace literatury a vyvozuje z ní radikální závěr? Totiž: před státní mocí není třeba nic skrývat, vždyt' nakonec váhu literární tvorbě v této situaci dodává kromě tautologického sebeujištování v rámci ghetta především závážnost, kterou připisuje literatuře státní moc. Přri vědomí, že tato situace není ani zdaleka „normální” se není třeba vyhýbat závěru, že StB jako dozorčí orgán státní moci představuje toho nejdůležitějš́ího čtenáře, protože „Většina národa už od literatury nic nečeká a odvykla si ji brát vážně a odvykla brát ji vůbec na vědomí” (Kratochvil 2005, s. 293). A takovému čtenáři přece nelze lhát.

\section{Př́pad Kratochvil}

V Kratochvilově povídce Přiběh krále Kandaula ze sbírky povídek Orfeus z Kénigu narazíme na následující scénu: vypravěč (zaměstnanec psychiatrické kliniky) dostává na starost Ludvíka (po pokusu o sebevraždu), kdysi populárního, egocentrického člověka s úspěchy u žen. Ludvík chce, aby mu vypravěč jeden večer půjčil klíče od ordinace kvůli ženské návštěvě. Druhý den se vypravěč snaží rekonstruovat události minulé noci z několika indicií: nepatrně hnuté pohovky, téměř neznatelné stopy parfému a vlásenky. Když vypravěč Ludvíka konfrontuje s těmito indiciemi, ten tvrdí, že k žádné ženské návštěvě nedošlo, což potvrdí ošetřovatel, a vypravěč tak zjišt'uje:
I pochopil jsem, jak je představivost záludná. Jak je schopna vytvořit si z pouhého očekávání (a z jednoho falešného podnětu) celou skutečnost! Protože ted’ už mi bylo jasné, že vlásenka patřila Věrušce, kantorce z gymnázia na Křenové, kterou v dobrém rozmaru a pro vaše potěšení nazvu svou snoubenkou. S pohovkou samozřejmě nebylo hnuto a parfém si můj nos - nemrava vymyslel (Kratochvil 1994, s. 44).

Zde se nezakrytě ukazuje, co lze chápat pod posthermeneutickým prríběhem $-\mathrm{v}$ daném př́ípadě se nejedná o falešnou interpretaci, vlastně se nejedná vůbec o interpretaci. Je to akt v silném smyslu toho slova. Vypravěč si ve své představivosti předem zkonstruoval jistou př́běhovou konstrukci a ta vytváří skutečnost. Vypravěč tedy chce najít indicie, které by danou verzi př́běhu potvrdily, a ty nachází $\mathrm{v}$ podobě fantazmatu. Interpretace se opírá o znaky, které jsou vytvořeny „falešně” (na somatické, senzorické úrovni, nemajíce oporu ve fenomenálním světě). Zkušenost je vytvořena subjektem. Tuto zkušenost však svědectví zneplatní. Vypravěč tu navíc paradoxně netouží po př́běhu, který by mu poskytl „štěstî” nebo uspokojení, ale po přiběhu, který prohloubí či stvrdí oprávněnost jeho závisti, uspokojí jeho touhu po sebemrskačství, sebeponížení. Už jsem zmínil, že hlavní ženská postava povídky, Svatava, je nemluvná: i v této scéně je žena paradoxním centrem interpretace - byla dosazena do struktury interpretované situace tam, kde nikdy nebyla. Žena nenabízí znaky, nedává se jako znak (bud’ nemluví, nebo je nepř́tomná), a představuje tak pro mužskou interpretaci nepřekonatelný problém.

Stejně jako Vaculík i Kratochvil zachycuje ve své povídce „výrobu" literatury. U Kratochvila se postava Ludvíka inspiruje vypravěčovým nápadem s literární mystifikací a nechá Svatavu, svi̊j objev, publikovat jeho vlastní texty, a ty jsou kritikou více než nadšeně príijaty, když sám Ludvík s nimi nikdy předtím neměl v redakcích časopisů úspěch. Nesoulad mezi představou jak by měl vypadat „mužský” $a$,ženský” subjekt básně, ale především Svatavin půvab a nemluvnost vedou k literární senzaci: čtenáři a kritika jsou ochotni, připraveni nechat se mystifikovat, vedeni falešnými, romantickými představami o literatuře, o tvưrci jako géniovi apod. Situace je vlastně analogická výše popsané scéně, přičemž podlehnutí zjevně „neadekvátnímu” 
výkladu může být zcela vědomé, jako je tomu ve scéně televizního interview se známým anglickým básníkem:

Svatavu by moc zajímalo - řekl Ludvík - jestlipak, Mistře, víte o tom, že tajemná dívka s mateřským znaménkem na pravém boku, Vaše nebeská konkubína, s níž kopulujete ve snu, jenž popisujete ve dvaašedesátém sonetu sbírky Písně z malin a ostružiní, je ve skutečnosti Svatava? A sir Edward po celou dobu, co Ludvík kladl otázku, patřil na Svatavu a hleděl na ni mlčky ještě chvíli poté, co už byla otázka zcela položena a přeložena. A pak teprve pomalu a tiše odpověděl: Ano, vím o tom. Hned jsem ji poznal. [...] A ještě něco, miláčkové: sir Edward samozrejmě nenapsal žádný dvaašedesátý sonet a dokonce žádnou sbírku Písně z malin a ostružiní! (Kratochvil 1994, s. 49)

I zde přichází neznámo odkud příběh, jenž se nám nabízí $\mathrm{k}$ věření a verifikaci. Akt přitakání této podobě príběhu ze strany „Mistra” je tím, co dodává celé situaci punc pravosti: před tímto aktem nebylo nic, snad jen prázdno uvnitř subjektu, které je náhražkovitě zaplňováno nabízející se identifikací se sexuálně literárním subjektem. Zde nelze určit hranici mezi mystifikací a pravdou (jako u Vaculíka nelze rozlišovat mezi deníkem a románem): přitakáním se mění pravidla hry, mění se skutečnost, přinejmenším pro onoho „známého anglického básníka" - ale také pro všechny ty, kdo televizní interview sledují. Symbolický režim jazyka přivádí odnikud na svět skutečnost: tam, kde je ted” „nebeská konkubína” nebylo nic, jen připravené prázdné místo uvnitř intersubjektivních vztahů, které Jacques Lacan nazývá „objekt malé $a$ ” (,objet petit a” - od „petit autre”, „,malý druhý”). Tato struktura ukazuje střed mé subjektivity jako prázdný s tím, že je možné jej zaplňovat právě jen „fikcí” či symbolickými řečovými akty. Což znamená, že k ,zaplnění/naplnění”, ke konečné sebe-identifikaci nikdy nedojde. Jsem to tedy skutečně,,já", kdo interpretuje, nebo je to cosi neznámého, neurčitelného, nepojmenovatelného uvnitř mě, odkud vychází můj náhled na svět, na ostatní lidské subjekty? Jsme schopni rozpoznat skutečnost? „Skutečnost” mlčí, je to onen nemluvný preontologický základ, na nějž prostřednictvím (především) jazykových aktů promítáme své príběhy, svá fantazmata.

Co prozrazuje úspěšnost Ludvíkovy literární mystifikace? Cosi velmi podobného zvrácenosti postavení literatury $\mathrm{v}$ „reálném socialis- mu”, jak se s ní potkáváme u Vaculíka. Zdá se, že postmoderna (jak ve smyslu „umělecko-filozofického směru”, tak ve smyslu „dějinného období následujícího po moderně”) tu odkrývá literaturu jako zbytnou, jako cosi, co v podobě uměleckých děl putujících časem (tzv. klasických děl) má jen fantomatickou váhu či závažnost (a proto je možné si s nimi „hrát”). Literatura o sobě, ze sebe už žádnou váhu nemá, nebo jen minimální, je třeba ji podepřít dodatečně nějakou institucí (státní mocí, zabudováním výuky literatury do pedagogického procesu, nebo aktem „víry”). A tato potřebnost garance přicházející zvnějšku poukazuje na fundamentální nicotu uvnitř literární struktury, kterou si pro změnu západní kultura promítá do svého centra. Postmoderna bere vážně Hamletovu odpověd' na otázku po tom, co že to vlastně coby čtenáři čteme. Slova, slova, slova. A za nimi? Př́zraky, prázdno. Snad proto je tolik postmoderních romanopisců zároveň kritiky či dokonce liteárními teoretiky (John Barth, Raymond Federman, Jean Ricardou, Philippe Sollers aj.). Př́iběh se skrze literárněteoretický komentár̆ dovolává literatury jako literatury, a staví nás před základní situaci umění, jež spočívá v konfrontaci s nicotou, jak ve svém výkladu orfeovského mýtu naznačuje Maurice Blanchot:

Za jménem, které ji [Eurydiku] skrývá, a za závojem, který ji halí, je hluboce temným bodem, k němuž, jak se zdá, směřuje umění, touha, smrt i noc. Je okamžikem, kdy se esence noci přibližuje jakožto druhá noc (Blanchot 1999, s. 231).

Avšak Orfeus, pokračuje Blanchot, má za úkol přivést toto temné centrum na světlo a dát mu tvar, „ale jedině, když od něj bude odvrácen. Toto odvrácení je jediný prostředek, jak se k němu přiblížit" (Blanchot 1999, s. 231).

Kratochvil svým groteskním pohledem na „výrobu” umění poukazuje na to, co nám vlastně postmoderna provedla, když nám nedá zapomenout na vratké založení západní kultury $\mathrm{s}$ jejím specifickým vztahem ke knize, který má svůj počátek v judaismus a křest’anství. Ovšem kniha (umění, chcete-li), jak nám říká postmoderna, je především oním orfeovským pohledem do propasti (srov. Hassanovy interpretace orfeovského mýtu; Hassan 1967, 1982). 
Západní kultura jako kultura knihy je nucena replikovat tuto kulturní strukturu, tedy chápat literaturu jako cosi závažného, aby se celá budova nerozpadla a nevyjevila se neopodstatněnost, mystičnost, metafyzičnost takového založení. Noci není možné pohlédnout do tváře a nezaplatit za to cenu nejvyšší. Postmoderna nám sice odhaluje, že literatura je zbytečná, ale zároveň nás tak staví před volbu etickou. A jediným etickým činem tváří v tvář takové ,,pravdě” postmoderny je lež: literature matters. Literatura představuje soubor symbolických systémů, které nám propůjčují identitu coby obyvatelům západního světa, na úrovni čtenářského prožitku pak umožňuje testovat různé životní př́iběhové scénáře. Gesto ,známého anglického básníka” tedy není gestem perverzního starce: je to gesto sebezáchovné a jediné možné - lež je pravda, jen zdánlivě se zde objevuje možnost odpovědět jinak: pravdou je nutnost lhát. A proto se nedomnívám, že „literární jazyk je, a vždy bude, parazitovat na běžném jazyce, a zvláště na běžném jazyce morálky. Dále, literární zájmy budou vždy parazitovat na zájmech morálních. Konkrétně nemůžete stvořit nezapomenutelnou literární postavu bez toho, abyste tím čtenáři nepodali návrh jeho vlastního jednání" (Rorty 1989, s. 167). Přinejmenším pokud nahradím termín ,literatura” označením ,„příběh”, přičemž prostřednictvím př́běhů jako obyvatel světa rozvrhuji a projektuji svou žitou skutečnost a z pozice vědomě konečného, smrtelného subjektu konkrétním způsobem vytváŕím jeho časovou strukturu, potom jsou „literární jazyk”, ,,běžný jazyk” a ,,jazyk morálky” přinejmenším rovnocenné.

Zde je třeba uvést ještě poslední podobu ,posthermeneutického příběhu" jak ji nacházíme v Kratochvilově povídce. Interpretaci tu nestojí v cestě ani tak fakt, že se Gygova a Kandaulova př́běhu v historii západní literatury chopilo hned několik autorů (např. Platón, Hérodotos, Théophile Gautier, Friedrich Hebbel, André Gide), jako spíše to, že se tento př́běh dovolává situace, která $\mathrm{z}$ principu hermeneutice vzdoruje, nebot' se neodehrává v symbolickém znakovém režimu. Kandaules dopřeje Gygovi pohled na svou nahou manželku, a chce od něj na oplátku jeho prsten, který činí člověka neviditelným. Gygés ale po královně zatouží a Kandaula zabije (snad dokonce s královninou pomocí). Tento základní prríběh se v povídce objevuje v několika podobách, nejvýznamnější je ta, ve které Ludvík dopřává vypravěči pohled na nahou Svatavu, a to $\mathrm{s}$ jejím svolením, což ale vypravěč hned neuhodne. Ludvík v Kratochvilově povídce také nakonec umírá a vypravěč jej posléze „nahrazuje”. Kratochvil tedy poněkud pozměňuje základní Gygovu situaci, kterou Lévinas popisuje takto: „vidí ty, kdo jej pozorují, aniž jej vidí, a [...] ví, že není vidět" (Lévinas 1997, s. 74). Nepřístupnost této i vypravěčovy situace hermeneutice je možné spatřovat v tom, že se zde jedná pouze o pasivní dívání, vydělují se zde role diváka a herce, nestojí tu „tvárí v tváŕ” dva subjekty, ale subjekt a objekt. Svatava je v tomto „divadelním představení” zcela nahá, jen na očích má dva zelené lístky, které jí především znemožňují „,vrátit pohled”, a tím ji ještě důsledněji činí onou „Věcí”, jak o ní hovoří Žižek. Lévinas pokračuje:

Není však v Gygově postavení zahrnuta beztrestnost jediné bytosti na světě, to jest bytosti, pro kterou je svět divadlem? A není právě toto sama podmínka osamělé a právě proto nepopírané svobody, podmínka jistoty? Není tento mlčenlivý svět - to jest toto čisté divadlo - právě př́ístupný pravému poznání? (Lévinas 1997, s. 74).

Tady není třeba interpretovat, tady se mlčenlivý svět dává ve své nezakrytosti: za cenu zapomenutí jazyka, za cenu neuchopitelnosti a efemérnosti (což je podoba, kterou tu na sebe bere úvodem zmiňovaná ,preontologická prázdnota”). Ale Lévinas následně varuje před touto fascinací a nadějí, kterou se tento typ situace zdá nabízet:

Divadlo mlčenlivého světa faktů je začarované: každý fenomén do nekonečna maskuje, mystifikuje, takže aktualita tu není možná (Lévinas 1997, s. 75-76)

Subjekt, jenž pouze trpně pozoruje scénu a jemuž jeho pohled není či nemůže být vrácen, zakouší svou fundamentální prázdnotu, nemožnost založit svou vlastní subjektivitu jen z ní samotné. Tady končí veškerý komentářr.

\section{Literatura}

B 1 a n c h o t M., 1999, Literárni prostor, Praha. 
F 1 a x J., 1991, Thinking Fragments: Psychoanalysis, Feminism, and Postmodernism in the Contemporary West, Berkeley.

G e n e t t e G., 1983, Narrative Discourse: An Essay in Method, Ithaca.

G e n e $t$ t e G., 1988, Narrative Discourse Revisited, Ithaca.

H a s s a n I. H., 1967, Literature of Silence, New York.

H a s s a n I. H., 1982, The Dismemberment of Orpheus: Toward a Postmodern Literature, Madison.

J a m e s o n F., 1971, Metacommentary, „PMLA” MXXXVI, č. 1, s. 9-18.

Jirs a T., 2016, Tvář́ v tvár beztvarosti: Afektivní a vizuální figury v moderní literatuře, Brno.

K r a t o c h vi 1 J., 1994, Orfeus z Kénigu, Brno.

K r a t o c h v il J., 2005, Literatura ted', [in:] Z dějin českého myšleni o literature 4 (1970-1989), ed. M. Přibáň, Praha, s. 282-297.

K riste v a J., 1986, Psychoanalysis and the Polis, [in:] The Kristeva Reader, ed. T. Moi, New York, s. 301-320.

L é v in a s E., 1997, Totalita a nekonečno, Praha.

L y o t a r d J.-F., 1993, O postmodernismu, Praha.

Mer s c h D., 2010, Posthermeneutik, Berlin.

Ri ch te rová S., 1991, Slova a ticho, Praha.

R or ty R., 1989, Contingency, Irony, and Solidarity, New York.

S u c h o m e 1 M., 1997, Postmodernism in Czech Literature, [in:] International Postmodernism - Theory and Literary Practice, ed. H. Bertens a D. Fokkema, Amsterdam-Philadelphia, s. 419-422.

V a c u lík L., 1990, Český snár̆, Brno.

Žižek S., 1992, Enjoy your Symptom! Jacques Lacan in Hollywood ond out, London

Ži že k S., 2007, Nepolapitelný subjekt: chybějicí střed politické ontologie, Cho- 